\title{
PERSEPSI ATAS SANKSI PERPAJAKAN TERHADAP KEPATUHAN WAJIB PAJAK ORANG PRIBADI PADA KPP MAKASSAR SELATAN
}

\author{
Andi Rustam ${ }^{1}$ Saida Said ${ }^{2}$ \\ Universitas Muhammadiyah Makassar \\ e-mail:d3pajak@unismuh.ac.id
}

\section{Abstract}

This research aims to test the influence of Fiskus service, level of understanding and taxation of tax compliance of individual taxpayers in Makassar Pratama Selatan. The Data in this study was obtained from the taxpayer registered with the KPP Pratama Makassar Utara which was willing to become a respondent. This research uses primary data by conducting direct research in the field by providing questionnaire/question sheets to 80 respondents. The method of data analysis used is analysis of multiple linear regression. The results showed that: in partial, variable Fischus services, the level of understanding and taxation sanctions are positive and significant to the individual taxpayers ' compliance in paying taxes.

Keywords: Fischus service, level of understanding, taxation and compliance of taxpayers

\begin{abstract}
Abstrak
Penelitian ini bertujuan untuk menguji pengaruh pelayanan fiskus, tingkat pemahaman dan sanksi perpajakan terhadap kepatuhan wajib pajak orang pribadi pada KPP Pratama Makassar Selatan. Data dalam penelitian ini,diperoleh dari wajib pajak yang terdaftar pada KPP Pratama Makassar Utara yang bersedia menjadi responden. Penelitian ini menggunakan data primer dengan cara melakukan penelitian langsung dilapangan dengan memberikan kuesioner/lembar pertanyaan kepada 80 responden. Metode analisis data yang digunakan yaitu analisis regresi linear berganda. Hasil penelitian menunjukkan bahwa: secara parsial, variabel pelayanan fiskus, tingkat pemahaman dan sanksi perpajakan berpengaruh positif dan signifikan terhadap kepatuhan wajib pajak orang pribadi dalam membayar pajak.
\end{abstract}

Kata kunci : Pelayanan fiskus, tingkat pemahaman, sanksi perpajakan dan kepatuhan wajib pajak 


\section{PENDAhuluan}

Sumber penerimaan negara Indonesia yang paling potensial adalah penerimaan pajak. Penerimaan pajak akan digunakan untuk membiayai pembangunan dan meningkatkan kesejahteraan seluruh rakyat Indonesia. Salah satu penerimaan pajak berasal dari Pajak Penghasilan (PPh). Pajak Penghasilan sendiri terbagi dua, yaitu Pajak Penghasilan yang berasal dari Badan dan Pajak Penghasilan yang berasal dari wajib pajak orang pribadi. (Mutia: 2008). Salah satu wajib pajak yang diminta untuk menghitung, menyetor, dan melaporkan besarnya pajak terutang adalah wajib pajak orang pribadi. Orang Pribadi sebagai subjek pajak pribadi yang menurut ketentuan peraturan perundang-undangan perpajakan ditentukan untuk melakukan kewajiban perpajakan termasuk pemungutan pajak atau pemotongan pajak, seharusnya dapat mengelola usaha individualnya dengan lebih baik dibandingkan usaha organisasi. Dengan struktur yang ada, orang pribadi dapat mengatur seluruh pengeluaran dalam kegiatan usahanya agar memperoleh keuntungan yang diinginkan termasuk dalam mengatur kewajiban perpajakannya.

Persentase penerimaan negara dari sektor pajak setiap tahun semakin meningkat, hal ini terlihat dalam APBN negara kita. Dari semakin meningkatnya persentase penerimaan pajak kita, hal tersebut berarti pemerintah masih dapat melakukan upaya-upaya untuk menggali potensi pajak dan mengoptimalkan penerimaan pajak. Upaya-upaya yang dapat dilakukan antara lain dengan ekstensifikasi pajak yaitu dengan menambah jumlah Wajib Pajak dan dengan intensifikasi pajak yaitu dengan mengaktifkan atau menggali potensi dari Wajib Pajak yang sudah ada Pada umumnya Wajib Pajak cenderung untuk menghindarkan diri dari pembayaran pajak. Kecenderungan ini terjadi karena adanya beberapa faktor yang menyebabkan Wajib Pajak enggan memenuhi kewajibannya untuk membayar pajaknya, seperti pelayanan cara petugas pajak dalam membantu, mengurus, atau menyiapkan segala keperluan yang dibutuhkan oleh Wajib Pajak (pelayanan fiskus). Persepsi wajib pajak tentang pelayanan fiskus dibentuk oleh dimensi kualitas sumber daya manusia (SDM).

Selain itu, beberapa fenomena kasus-kasus yang terjadi di dunia perpajakan Indonesia belakangan ini membuat wajib pajak dan masyarakat khawatir dan resah untuk membayar pajak. Kondisi itu dapat mempengaruhi kepatuhan wajib pajak. Kesadaran wajib pajak atas fungsi dan peran perpajakan sebagai pembiayaan pembangunan negara sangat diperlukan untuk meningkatkan kepatuhan wajib pajak. Sanksi perpajakan juga mempunyai pengaruh terhadap kepatuhan wajib pajak. Sanksi diperlukan untuk memberikan pelajaran atau hukuman bagi pelanggar pajak. Alifah Nur Rohmawati, dan Ni Ketut Rasmini (2012) membuktikan bahwa sanksi perpajakan berpengaruh signifikan terhadap kepatuhan wajib pajak orang pribadi. Sanksi perpajakan merupakan jaminan bahwa ketentuan peraturan perundang-undangan perpajakan akan dituruti atau ditaati atau dipatuhi, dengan kata lain sanksi perpajakan merupakan alat pencegah agar wajib pajak tidak melanggar norma perpajakan (Mardiasmo, 2009:57).

\section{TINJAUAN PUSTAKA}

\section{Pajak}

Gusfahmi (2007) "Pajak adalah kewajiban yang ditetapkan terhadap wajib pajak, yang harus disetorkan kepada negara sesuai dengan ketentuan, tanpa mendapat prestasi kembali dari negara, dan hasilnya untuk membiayai pengeluaran-pengeluaran umum di satu pihak dan untuk merealisasi sebagian tujuan ekonomi, sosial, politik dan tujuan-tujuan lain yang ingin dicapai oleh negara".Smeeths, pajak adalah sebuah prestasi pemerintah yang terhutang melalui norma-norma dan dapat dipaksakan tanpa adanya suatu kontra prestasi dari setiap individual. 


\section{Kepatuhan Wajib Pajak}

Pengertian kepatuhan Wajib Pajak menurut Nurmantu dalam Rahayu (2010), menyatakan bahwa: "Kepatuhan perpajakan dapat didefinisikan sebagai suatu keadaan dimana Wajib Pajak memenuhi semua kewajiban perpajakan dan melaksanakan hak perpajakannya".Menurut Keputusan Menteri Keuangan No. 544/KMK.04/2000 dalam Sony Devano dan Siti Kurnia Rahayu (2010), menyatakan bahwa: "Kepatuhan perpajakan adalah tindakan Wajib Pajak dalam pemenuhan kewajiban perpajakannya sesuai dengan ketentuan peraturan perundangundangan dan peraturan pelaksanaan perpajakan yang berlaku dalam suatu negara".

\section{Sanksi Perpajakan}

Mardiasmo (2003) sanksi perpajakan merupakan jaminan bahwa ketentuan peraturan perundang-undangan perpajakan (norma perpajakan) akan dituruti/ditaati/dipatuhi. Atau dengan kata lain sanksi perpajakan merupakan alat (preventif) agar wajib pajak tidak melanggar norma perpajakan. Dalam undangundang perpajakan dikenal dua macam sanksi, yaitu Sanksi Administrasi dan Sanksi Pidana. Ancaman terhadap pelanggaran suatu norma perpajakan ada yang diancam dengan sanksi administrasi saja, ada yang diancam dengan sanksi pidana saja, dan ada pula yang diancam dengan sanksi administrasi dan sanksi pidana

\section{METODE}

Pendekatan yang digunakan dalam penelitian ini adalah pendekatan kuantitatif dengan ilmiah yaitu berfikit untuk memecahkan masalah secara sistematis, empiris, dan terkontrol yang dengan angka-angka. Objek Penelitian dalam Pengambilan data dilakukan di KPP Makassar Selatan. Waktu Penelitian dilakukan mulai bulan januari-februari tahun 2016.. Populasi dalam penelitian ini adalah seluruh wajib pajak orang pribadi yang tercatat di KPP Pratama Makassar Selatan. Jumlah populasi dalam penelitian ini yaitu 59.179 wajib pajak orang pribadi guna efisiensi waktu dan biaya, maka tidak semua wajib pajak tersebut menjadi objek dalam penelitian ini. Oleh karena itu dilakukanlah pengambilan sampel. Pengambilan sampel dalam penelitian ini dilakukan dengan metode incidental. Adapun jenis data yang digunakan dalam penelitian ini adalah data kualitatif dan kuantitatof, sedangkan Sumber data yang diperoleh dalam penelitian ini adalah data primer dan sekunder.

\section{Metode Analisis Data}

Metode statistik yang digunakan untuk menguji hipotesis adalah dengan menggunakan regresi berganda dengan bantuan perangkat lunak SPSS for windows, setelah semua data data dalam penelitian ini terkumpul, maka selanjutnya dilakukan analisis data yang terdiri dari:

\section{Uji Statistik Deskriptif}

Statistik deskriptif memberikan gambaran atau deskripsi suatu data yang dilihat dari nilai rata-rata (mean), standar deviasi, varian, maksimum, minimum, sum, range, kurtosis dan skewness (Ghozali, 2009).

\section{Uji Kualitas Data}

Pengujian kualitas data yang dilakukan dengan cara penyebaran kuesioner, maka kesediaan dan ketelitian dari para responden untuk menjawab setiap pertanyaan merupakan suatu hal yang sangat penting dalam penelitian ini. Keabsahan suatu jawaban sangat ditentukan oleh alat ukur yang ditentukan. Untuk itu, dalam melakukan uji kualitas data atas data primer ini peneliti melakukan uji validitas dan uji reabilitas.

\section{Uji Asumsi Klasik}
a. Uji Normalitas
b. Uji Multikolinieritas
c. Uji Heteroskedastisitas

\section{Uji Hipotesis}

a. Uji Persamaan Regresi Linier Berganda 
Pengujian hipotesis ini dilakukan dengan menggunakan metode analisis regresi linier berganda yang bertujuan untuk menguji hubungan pengaruh antara satu variabel terhadap variabel lain. Variabel yang dipengaruhi disebut variabel tergantung atau dependen, sedangkan variabel yang mempengaruhi disebut variabel bebas atau independen. Model persamaannya dapat digambarkan sebagai berikut:

$$
\mathrm{Y}=\alpha+\beta 1 \times 1+\beta 2 \times 2+\beta 3 \times 3+\varepsilon
$$

\section{Keterangan:}

Y : Kepatuhan Wajib Pajak

X1: Pelayanan Fiskus

X2: Tingkat Pemahaman

X3: Sanksi Perpajakan

$\alpha$ : Konstanta

$\beta \mathrm{x}$ : Koefisien regresi

$\varepsilon$ : Error

\section{b. Uji $R 2$ (Koefisien Determinasi)}

Koefisien determinasi bertujuan untuk mengukur seberapa jauh kemampuan model dapat menjelaskan variasi variabel dependen. Dalam pengujian hipotesis pertama koefisien determinasi dilihat dari besarnya nilai $\mathrm{R}$ Square $(R 2)$ untuk mengetahui seberapa jauh variabel bebas yaitu pengetahuan tentang pajak, kesadaran perpajakan, dan sanksi perpajakan terhadap kepatuhan wajib pajak. Nilai R2 mempunyai interval antara 0 sampai $1(0 \leq \mathrm{R} 2 \leq$ 1). Jika nilai R2 bernilai besar (mendekati 1) berarti variabel bebas dapat memberikan hampir semua informasi yang dibutuhkan untuk memprediksi variabel dependen. Sedangkan jika $R 2$ bernilai kecil berarti kemampuan variabel bebas dalam menjelaskan variabel dependen sangat terbatas (Ghozali, 2009).

\section{c. Uji Statistik t}

Uji t dapat juga dilakukan dengan hanya melihat nilai signifikansi t. Masing - masing variabel yang terdapat pada output hasil regresi menggunakan SPSS. Jika nilai probabilitas lebih kecil dari pada 0,05 (untuk tingkat signifikansi $=5 \%$ ), maka variable independen secara satu persatu berpengaruh terhadap variable dependen. Sedangkan jika nilai probabilitas lebih besar dari pada 0,05 maka variabel independen secara satu persatu tidak berpengaruh terhadap variable dependen.

\section{d. Uji Statistik F}

Pengujian ini bertujuan untuk membuktikan apakah variabel-variabel independen (X) secara simultan (bersama-sama) mempunyai pengaruh terhadap variabel dependen (Y). (Ghozali, 2009). Apabila $\mathrm{F}$ hitung $>\mathrm{F}$ tabel, maka Ho ditolak dan Ha diterima, yang berarti variabel independen mempunyai pengaruh yang signifikan terhadap variabel dependen dengan menggunakan tingkat signifikan sebesar 5\%, jika nilai Fhitung > Ftabel maka secara bersamasama seluruh variabel independen mempengaruhi variabel dependen. Selain itu, dapat juga dengan melihat nilai probabilitas. Jika nilai probabilitas lebih kecil daripada 0,05 (untuk tingkat signifikansi $=5 \%$ ), maka variabel independen secara bersama-sama berpengaruh terhadap variabel dependen. Sedangkan jika nilai probabilitas lebih besar dari pada 0,05 maka variabel independen secara serentak tidak berpengaruh terhadap variabel dependen.

\section{HASIL DAN PEMBAHASAN}

\section{Hasil Uji Statistik Deskriptif}

Variabel yang digunakan dalam penelitian ini adalah kesadaran perpajakan, kualitas pelayanan pajak, pengetahuan tentang pajak dan motivasi wajib pajak.

Variabel-variabel tersebut akan di uji dengan statistik deskriptif.

Tabel 1. Analisis Statistik Deskriptif Descriptive Statistics

\begin{tabular}{llrrrr}
\hline & N & \multicolumn{1}{c}{ Minimum } & \multicolumn{1}{c}{ Maximum } & \multicolumn{1}{c}{ Mean } & \multicolumn{1}{c}{ Std. Deviation } \\
\hline SanksiPerpajakan & 80 & 20.00 & 25.00 & 23.1625 & 1.95807 \\
\hline
\end{tabular}




\begin{tabular}{llllll}
\hline KepatuhanWajibPajak & 80 & 18.00 & 25.00 & 22.2000 & 1.36317 \\
\hline Valid N (listwise) & 80 & & & & \\
\hline
\end{tabular}

Sumber: Data primer yang diolah, 2016

Tabel 1 menjelaskan hasil statistik deskriptif tentang variabel-variabel dalam penelitian ini, antara lain:

a. Pengetahuan Sanksi Perpajakan (X)

Berdasarkan Tabel 6diatas Sanksi Perpajakan memiliki nilai minimum 20, nilai maksimum 25, dan mean 23,1625 dengan 5 item pertanyaan maka $(23,1625: 5=4,6325)$ sehingga 4,6325 berada di skala nilai yang menunjukkan pilihan jawaban sangat setuju. Nilai standar deviasimenunjukkan adanya penyimpangan sebesar 1,95807 dari nilai ratarata jawaban responden. b. Kepatuhan Wajib Pajak (Y)

Berdasarkan Tabel 6diatas Kepatuhan Wajib Pajak memiliki nilai minimum 18 , nilai maksimum 25, dan mean 22,2 dengan 5 item pertanyaan maka $(22,5: 5=4,44)$ sehingga 4,44berada di skala nilai yang menunjukkan pilihan jawaban sangat setuju. Nilai standar deviasi menunjukkan adanya penyimpangan sebesar 1,36317 dari nilai rata-rata jawaban responden.

\section{Hasil Uji Asumsi Klasik}

a. Uji Normalitas

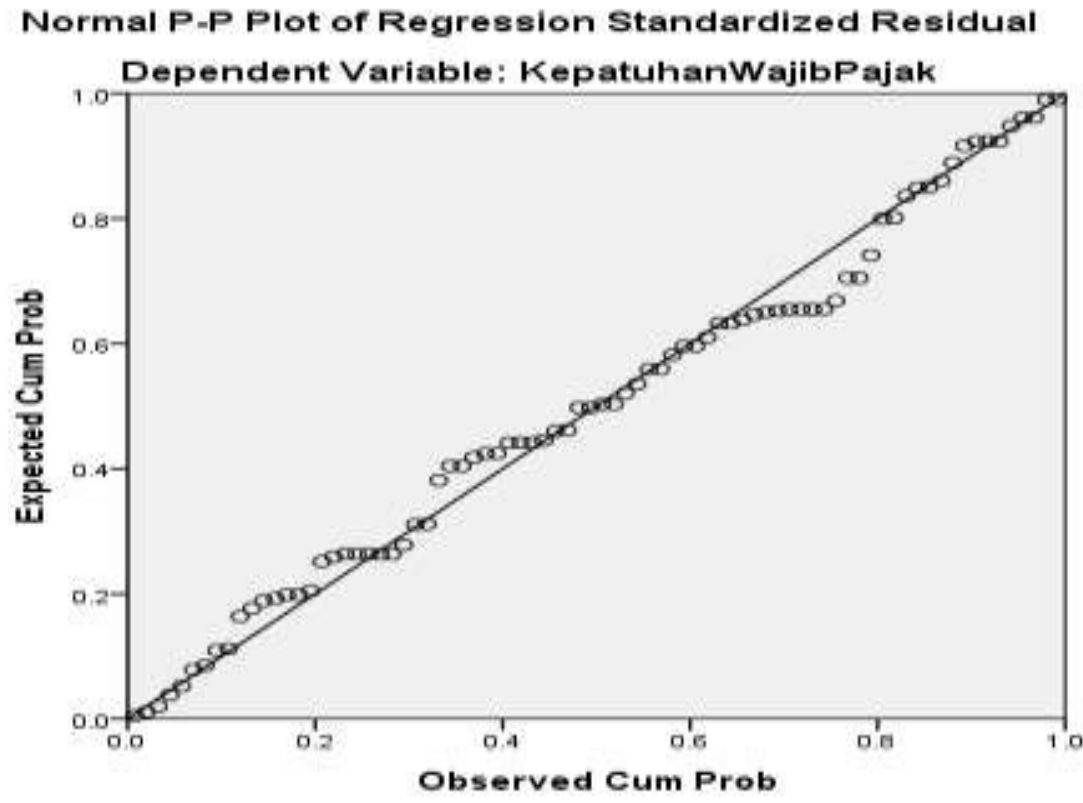

b. Hasil Uji Multikolinieritas

Hasil pengujian multikolinieritas dapat dilihat pada tabel berikut ini:

Tabel 2. Hasil Uji Multikolinieritas

Coefficients $^{\mathbf{a}}$

\begin{tabular}{ccc}
\hline \multirow{2}{*}{ Model } & \multicolumn{3}{c}{ Collinearity Statistics } \\
\cline { 2 - 3 } & Tolerance & VIF \\
\hline 1 (Constant) & & \\
\hline SanksiPerpajakan & .942 & 1.062 \\
\hline
\end{tabular}

Dependent Variable: KepatuhanWajibPajak

Sumber: Data yang diolah, 2016 
Berdasarkan Tabel 2, terlihat bahwa variabel sanksi perpajakan memiliki nilai tolerance diatas 0,1 dan VIF lebih kecil dari 10.
Hal ini berari dalam model persamaan regresi tidak terdapat gejala multikolonearitas sehingga data dapat digunakan dalam penelitian ini. c. Hasil Uji Heteroskedastisitas

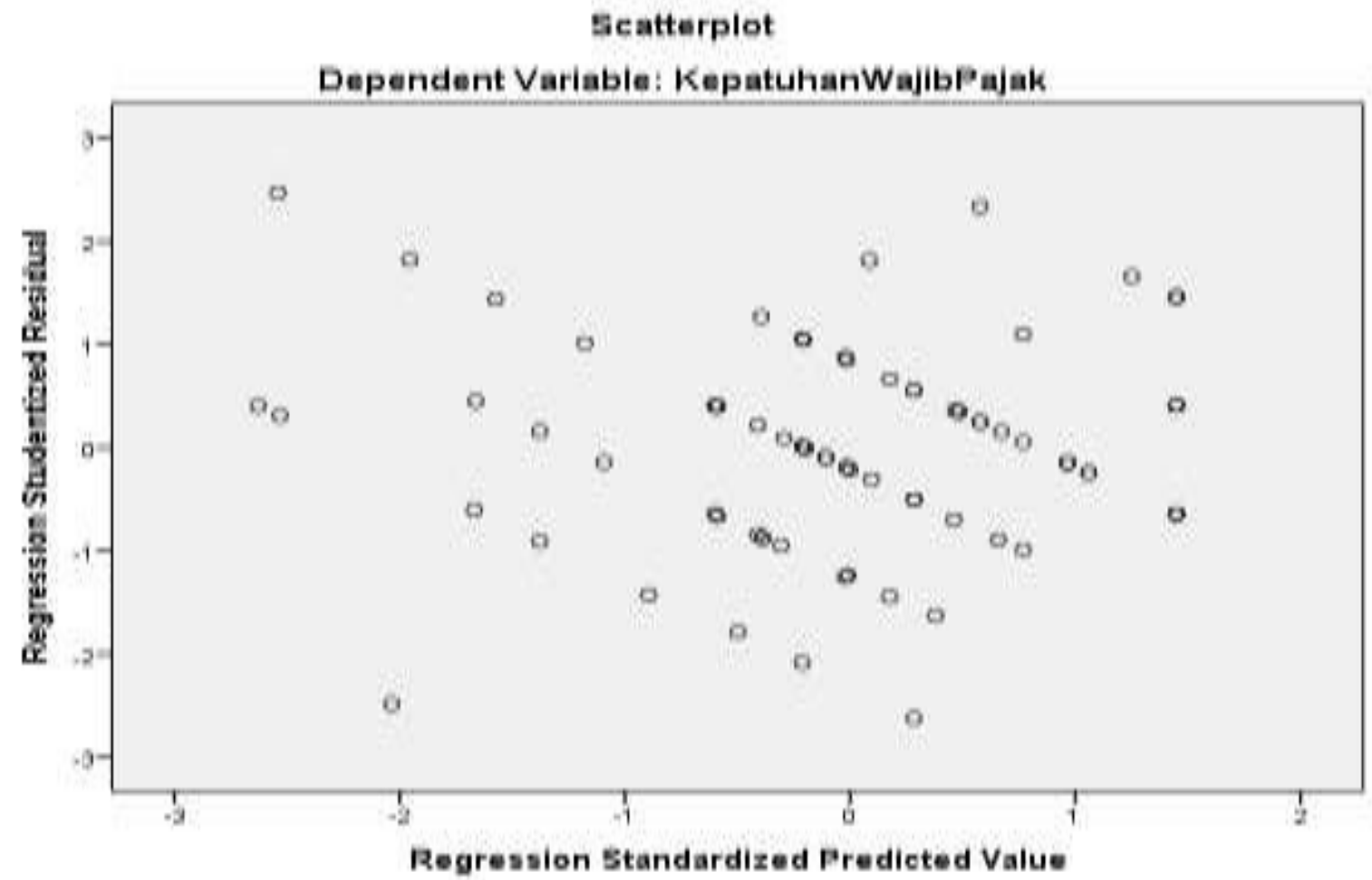

Hasil Uji Hipotesis

Analisis Regresi Linear Berganda

Setelah hasil uji asumsi klasik dilakukan dan hasilnya secara keseluruhan menunjukkan model regresi memenuhi asumsi klasik, maka tahap berikut adalah melakukan evaluasi dan interpretasi model regresi berganda.

Tabel 3. Model Persamaan Regresi

Coefficients $^{\mathrm{a}}$

\begin{tabular}{ccccccc}
\hline \multirow{2}{*}{ Model } & \multicolumn{2}{c}{ Unstandardized Coefficients } & Standardized Coefficients & \multirow{2}{*}{$\mathrm{t}$} & & \multirow{2}{*}{ Sig. } \\
\cline { 2 - 6 } & $\mathrm{B}$ & Std. Error & Beta & & & 0.044 \\
\hline (Constant) 1 & 4.146 & 2.026 & & & 2.047 & 0.277 \\
\hline SanksiPerpajakan & 0.193 & 0.057 & 3.356 & 0.001 \\
\hline
\end{tabular}

Dependent Variable: KepatuhanWajibPajak

Sumber: Data yang diolah, 2016

Berdasarkan tabel diatas, maka persamaan regresi yang terbentuk pada uji regresi ini adalah:

$$
Y=4,146+0,193 X
$$

Model tersebut dapat diinterpretasikan adalah Koefisien regresi sanksi perpajakan $\left(b_{3}\right)$ adalah 0,193 dan bertanda positif. Hal ini berarti, jika nilai variabel $\mathrm{X}_{3}$ (Sanksi Perpajakan) mengalami kenaikan satu satuan dan variabel independen lainnya bernilai tetap nilai variabel $\mathrm{Y}$ (Kepatuhan Wajib Pajak) akan mengalami kenaikan sebesar 0,193. Koefisien bertanda positif menunjukkan adanya hubungan yang searah antara variabel sanksi perpajakan $\left(\mathrm{X}_{3}\right)$ dengan variabel kepatuhan wajib pajak (Y). Semakin tinggi sanksi perpajakan yang diterima oleh wajib pajak maka semakin tinggi kepatuhan wajib pajak dalam membayar pajak. 
Hasil uji hipotesis menunjukkan bahwa sanksi perpajakan berpengaruh positif dan signifikan terhadap kepatuhan wajib pajak. Ketika sanksi yang diberikan tinggi, maka wajib pajak tersebut termotivasi dan patuh untuk membayar pajak. Wajib pajak akan memenuhi pembayaran pajak bila memandang sanksi pajak akan lebih merugikannya, berdasarkan hal ini dan juga hasil penelitian dapat diartikan bahwa wajib pajak memenuhi kewajiban perpajakan dikarenakan wajib pajak berpikir bahwa sanksi pajak sangat merugikannya. Apabila wajib pajak tidak memenuhi kewajiban perpajakannya sesuai dengan peraturan yang berlaku, maka hukuman berupa denda atau pidana akan dihadapi oleh wajib pajak. Hal ini tentu sangat merugikan bagi wajib pajak, sehingga wajib pajak akan takut untuk melanggar peraturan perpajakan yang berlaku dan akan cenderung patuh memenuhi kewajiban perpajakannya.

Penelitian ini sejalan dengan penelitian yang dilakukan oleh Hadi (2010) yang meneliti kepatuhan wajib pajak orang pribadi di KPP Bukit tinggi menemukan bahwa sanksi perpajakan berpengaruh signifikan positif terhadap kepatuhan wajib pajak orang pribadi. Pengenaan sanksi perpajakan kepada orang pribadi yang berusaha menyembunyikan objek pajaknya dan tidak memenuhi kewajiban perpajakannya dapat menyebabkan terpenuhinya kewajiban perpajakan oleh wajib pajak sehingga dapat meningkatkan kepatuhan wajib pajak itu sendiri dalam membayar pajak. Hal ini terjadi karena wajib pajak akan merasa takut dan terbebani oleh sanksi yang akan dikenakan kepadanya karena melalaikan kewajiban perpajakannya.

Wajib pajak akan mematuhi pembayaran pajaknya bila memandang bahwa sanksi akan lebih banyak merugikannya (Jatmiko, 2006). Sanksi pajak merupakan jaminan bahwa ketentuan peraturan perundang-undangan perpajakan (norma perpajakan) akan dituruti/ditaati/dipatuhi, dengan kata lain sanksi perpajakan merupakan alat pencegah agar wajib pajak tidak melanggar norma perpajakan
(Mardiasmo, 2006) dalam (Muliari dan Setiawan, 2010).

\section{KESIMPULAN DAN SARAN}

\section{Kesimpulan}

Berdasarkan data yang telah dikumpul dan pengujian hipotesis dengan analisis regresi linear berganda telah dilakukan, maka kesimpulan dari penelitian ini adalah sebagai berikut:

a. Sanksi perpajakan memiliki pengaruh terhadap kepatuhan wajib pajak, Ketika sanksi yang diberikan tinggi, maka wajib pajak tersebut termotivasi dan patuh untuk membayar pajak. Wajib pajak akan memenuhi pembayaran pajak bila memandang sanksi pajak akan lebih merugikannya, berdasarkan hal ini dan juga hasil penelitian dapat diartikan bahwa wajib pajak memenuhi kewajiban perpajakan dikarenakan wajib pajak berpikir bahwa sanksi pajak sangat merugikannya.

b. Sanksi Perpajakan memiliki pengaruh terhadap kepatuhan wajib pajak. Dikarenakan jika kualitas pelayanan pajak yang diberikan oleh KPP Pratama Makassar Selatan sangat baik, wajib pajak juga mengetahui fungsi dari membayar pajak, serta mengetahui kerugian tidak membayar pajak akibat sanksi yang diberikan. maka wajib pajak semakin termotivasi dan patuh dalam membayar pajak.

\section{Saran}

Saran-saran yang dapat diberikan untuk penelitian selanjutnya adalah sebagai berikut:

a. Sampel dalam penelitian ini sedikit dan hanya terbatas pada wajib pajak yang terdaftar pada KPP Pratama Makassar Selatan. Disarankan Penelitian selanjutnya dapat menambah serta memperluas wilayah dan jumlah sampel.

b. Penelitian selanjutnya sebaiknya menambah jumlah variable baru selain dalam penelitian ini agar lebih mengetahui factor-faktor apa saja yang dapat mempengaruhi kepatuhan 
wajib pajak. Karena masih terdapat variabel lain yang mempengaruhi kepatuhan wajib pajak selain variable penelitian ini, seperti pengetahuan tentang pajak dan kesadaran perpajakan.

c. Penelitian ini diharapkan dapat memberikan masukan dan pertimbangan bagi KPP Pratama Makassar Selatan terkait untuk lebih meningkatkan kualitas pelayanan perpajakan. Hal ini terkait dengan kesadaran perpajakan, kualitas pelayanan pajak dan pengetahuan tentang pajak berpengaruh positif dan signifikan terhadap motivasi wajib pajak

\section{REFERENSI}

Adiasa, Nirawan. 2013. Pengaruh Pemahaman Peraturan Pajak Terhadap Kepatuhan Wajib Pajak Dengan Preferensi Risiko Sebagai Variabel Moderating. Skripsi. Semarang: Fakultas Ekonomi. Universitas Negeri Semarang.

Anggraini, Fibria. 2014. Faktor-Faktor yang Mempengaruhi Kepatuhan Wajib Pajak Orang Pribadi. e-Journal Magister Akuntasi Trisakti, Vol. 1 No. 1,Nopember 2015 Hal. 51-68.

Boediono. 2007. Pelayanan Prima Perpajakan.Rineka Cipta. Jakarta.

Fazrin, Noviana. 2014. Pengaruh Sikap Wajib Pajak, Motivasi Wajib Pajak, Kepribadian Wajib Pajak, Kesadaran Wajib Pajak, Pelayanan Perpajakan Dan Kepatuhan Wajib Pajak Terhadap Kinerja Penerimaan Pajak. Skipsi. Kudus: Fakultas Ekonomi. Universitas Muria Kudus.

Fermatasari, Dewi. 2010. Pengaruh Pengetahuan Pajak Dan Sanksi Pajak Terhadap Kepatuhan Wajib Pajak. Skripsi. Bandung: Fakultas Ekonomi dan Bisnis. Universitas Padjadjaran.
Gusfahmi. 2007. Pajak Menurut Syari'ah. PT Raja Grafindo Persada. Jakarta.

Jatmiko, Agus Nugroho. 2006. Pengaruh Sikap Wajib Pajak Pada Pelaksanaan Sanksi Denda, Pelayanan Fiskus, dan Kesadaran Perpajakan Terhadap Kepatuhan Wajib Pajak Studi Empiris Terhadap Wajib Pajak Orang Pribadi di Kota Semarang. Tesis. Semarang: Fakultas Ekonomi. Universitas Diponegoro.

Josephine, Prajogo Nidya. Pengaruh Tingkat Pemahaman Peraturan Pajak WAjib Pajak, Kualitas Pelayanan Petugas Pajak Dan Persepsi Atas sanksi Perpajakan Terhadap Kepatuhan Wajib Pajak UMKM Di Wilayah Sidoarjo. Tax \& Accounting Review, Vol. 3, No.2, Nopember 2015.

Judisseno, Rimsky K. 1999. Pajak dan Strategi Bisnis. PT. Gramedia Pustaka Utama. Jakarta.

Lusiana. 2015. Pengaruh Kesadaran, Pelayanan Fiskus dan Sanksi Perpajakan Terhadap Kepatuhan Wajib Pajak Orang Pribadi. Skripsi. Semarang: FakultasEkonomi, Universitas Semarang.

Lian, Saputra Ade. Pengaruh Keatuhan Wajib Pajak, Pengetahuan Pajak Dan Kualitas Pelayanan Terhadap Kepatuhan Wajib Pajak Reklame. Skripsi. Palembang: STIE MPD.

Mardiasmo, Andi. 2006. Perpajakan. Edisi Revisi. Yogyakarta.

Mardiasmo, Andi. 2013. Perpajakan. Edisi Revisi. Jilid 1. Yogyakarta.

Muliari, Ni Ketut. 2010. Pengaruh Persepsi tentang Sanksi Perpajakan dan Kesadaran Wajib Pajak Pada Kepatuhan Pelaporan 
Wajib Pajak Orang Pribadi Di Kantor Pelayanan Pajak Pratama Denpasar Timur. Skripsi. Bali: Fakultas Ekonomi. Universitas Udayana.

Mutia Tita Putri, Sri. 2014. Pengaruh Sanksi Perpajakan, Kesadaran Perpajakan, Pelayanan Fiskus dan Tingkat Pemahaman Terhadap Kepatuhan Wajib Pajak Orang Pribadi. Jurnal Akuntansi, Vol. 2, No. 1, 11 Nopember 2015.

Nurmantu, Safri. 2007. Faktor- Faktor yang mempengaruhi Pelayanan Perpajakan. Jurnal Ilmu Adminstrasi dan Organisasi, Jurnal Bisnis \& Birokrasi, Vol. 15, No.1, 11 Nopember 2015.

Pranadata, I Gede Putu. 2014. Pengaruh Pemahaman Wajib Pajak, Kualitas Pelayanan Perpajakan, dan Pelaksanaan Sanksi Pajak, Terhadap Kepatuhan Wajib Pajak Orang Pribadi Pada KPP Pratama Batu. Skripsi. Malang: Fakultas Ekonomi dan Bisnis. Universitas Brawijaya.

Robbins, Steppen P. 2011, Organization Behavior. Edisi Bahasa Indonesia. Pearson Education Asia Pte Ltd. Jakarta.

Rohmawati, Alifa Nur. 2012. Pengaruh Kesadaran, Penyuluhan, Pelayanan, dan Sanksi Perpajakan pada Kepatuhan Wajib Pajak Orang Pribadi, Skripsi. Bali: Fakultas Ekonomi. Universitas Udayana.

Rahayu, Siti Kurnia. 2010. Perpajakan Indonesia: Konsep dan Aspek Formal. Graha Ilmu. Yogyakarta.

Soemitro, Rahmat, dkk. 2006. Pajak Bumi dan Bangunan. Edisi Revisi. Refika. Bandung.

Syahril, Farid. 2013. Pengaruh Tingkat Pemahaman Wajib Pajak Dan Kualitas Pelayanan Fiskus Terhadap Tingkat Kepatuhan Wajib Pajak Pph Orang
Pribadi. Skripsi. Padang: Fakultas Ekonomi, Universitas Negeri Padang

Utami, Thia Dwi. Dan Kardinal. 2013. Pengaruh Kesadaran Wajib Pajak dan Sanksi Pajak Terhadap Kepatuhan Wajib Pajak Orang Pribadi pada Kantor Pelayanan Pajak Pratama Palembang Seberang Ulu. Jurnal. STIE MDP.

Waluyo, 2010. Perpajakan Indonesia, Jilid 1, Edisi Revisi, Jakarta: Salemba Empat

Winerungan, Oktaviane Lidya., 2013, Sosialisasi Perpajakan, Pelayanan Fiskus Dan Sanksi Perpajakan Terhadap Kepatuhan WPOP, Jurnal EMBA, Vol. 1, No. 3, 10 Nopember 2015.

Zahidah, Choiriyatuz. 2010. Pengaruh Tingkat Pemahaman dan Kepatuhan dan Ketegasan Sanksi Perpajakan Terhadap Kewajiban Perpajakan Pengusaha Usaha Kecil Menengah (UKM) Di Wilayah Jakarta Selatan. Skripsi. Jakarta: Fakultas Ekonomi. Universitas Islam Negeri Syarif Hidayatullah.

Zain, Mohammad. 2007. Manajemen Perpajakan.Salemba Empat. Jakarta. 